\begin{tabular}{lccc} 
VERSITA & GOSPODARKA & SUROWCAMI & MINERALNYMI \\
\hline \multirow{2}{*}{ Tom 29} & 2013 & Zeszyt 4 \\
& & DOI 10.2478/gospo-2013-0042 &
\end{tabular}

\title{
Changes in the sorption/diffusion kinetics of a coal-methane system caused by different temperatures and pressures
}

\section{Introduction}

The release of methane from coal can be described by unipore or bidisperse models (Clarkson, Bustin 1999). In this paper, the unipore diffusion model (Crank 1975) was used to determine the diffusion coefficient $D$. The internal structure of coal determines the kinetics of the release of methane from coal (Kovaleva, Solov'eva 2006). The unipore model best describes the diffusion in bright, vitrinite rich coals. As its name suggests, the unipore model is based on the assumption that the pore sizes of the porous material (coal) are similar.

This analysis considered the process of gas accumulation on a loose grained sorbent sample. The sample is saturated with sorbed gas under selected pressure. The release of gas is caused by the reduction of gas pressure surrounding the sample. It is assumed that the diffusion is an isothermal process. The transport of gas molecules inside the grains can be described as a combination of several different types of diffusion in a porous system (King, Ertekin 1989). The diffusion is driven by the concentration gradient of the deposited gas particles. It is assumed that the sorption and desorption processes occur instantaneously. The diffusion in the grains determines the kinetics of the process of accumulation and the release of sorbate (Kawęcka 1988).

This reasoning is the basis of the unipore model, which is a typical approach to obtain the diffusion coefficient D. The mathematical solution of the unipore model, describing

* Ph.D. Eng., Instytut Mechaniki Górotworu PAN, Kraków, Poland; e-mail: wierzbic@img-pan.krakow.pl 
the change in the volume or mass of the gas sorbed at a given time is presented by Crank (1975):

$$
\frac{v(t)-v(\infty)}{v(0)-v(\infty)}=\frac{6}{\pi^{2}} \sum_{1}^{\infty}\left[\frac{1}{n^{2}} \exp \left(-\frac{n^{2} \pi^{2} D t}{r^{2}}\right)\right]
$$

where:

$v(t) \quad-\quad$ is the total amount of gas adsorbed/desorbed at time $t$,

$v(\infty)$ - is the total amount of gas adsorbed/desorbed at indefinite time,

$D \quad-$ is the diffusion coefficient $\left[\mathrm{cm}^{2} / \mathrm{s}\right]$,

$R \quad-$ is the diffusion path length (grain radius) [cm].

This solution, based on Crank's paper, can be found in many publications such as (Laxminarayana, Crosdale 2002; Bhowmik, Dutta 2013; Han et al. 2013). To describe the kinetic diffusion/sorption processes, the diffusion coefficient $D$ with the physical dimension $\mathrm{cm}^{2} / \mathrm{s}$ or the effective diffusivity $D_{e}$, which is the ratio of the diffusion coefficient and the square diffusion path length, $D_{e}=D / R^{2}$ can be used. The physical dimension of $D_{e}$ is $s^{-1}$.

A review of prior studies shows that the value of the diffusion coefficient $D$ depends on the type of gas. A much higher diffusion coefficient exists during $\mathrm{CO}_{2}$ sorption on coal when compared to $\mathrm{CH}_{4}$ (Clarkson, Bustin 1999; Bhowmik, Dutta 2013; Charrière et al. 2010). The effect of gas pressure (concentrations) on the value of the diffusion coefficient has also been identified, but there is no clear opinion on this issue. Some studies showed an increase in the diffusion parameters with increasing pressure (Nandi, Walker 1975; Busch et al. 2004; Charriere et al. 2010), while other examples showed an inverse relationship (Cui et al. 2004). Pillalamarry et al. (2011) produced a graph indicating a decrease in the diffusion coefficient $D$ with increasing pressure. Changes in the diffusion coefficient value are great and reach half of the order of magnitude. A review of information on this topic can be found in the paper by Bhowmik and Dutta (2013).

The unipore model contains many assumptions that cannot be fully fulfilled. One of them is the assumption of the linear Henry's isotherm. The sorption of methane on coal is strongly non-linear. The consequence is uncertainty in the determination of the value of the effective diffusion coefficient. Some problems with the unipore model were discussed by Clarkson and Bustin (1999). The analysis of existing documentation on diffusion kinetics seems to show that the diffusion coefficient $D$ by Cank may not be a material constant.

Knowledge of the kinetic properties of the coal-gas system are important in terms of methane hazard in coal mines (Patyńska 2013), gas and coal outbursts danger (Młynarczuk, Wierzbicki 2009; Skotniczny 2009; Skoczylas 2012, 2012a) and $\mathrm{CO}_{2}$ sequestration in coal seams (Czerw, Ceglarska-Stefańska 2008) and for mining safety (Skotniczny 2013). 


\section{Sorption measurements}

\subsection{Investigation method}

The research concerning the sorption kinetics of methane on coal was performed under isothermal-isobaric conditions using the gravimetric method, described in the papers (Saghafi et al. 2007; Busch, Gensterblum 2011). The sample weight was about $100 \mathrm{mg}$. If the methane density and the weight changes are known, the amount of methane on coal can be calculated as a function of the time elapsed from the start of the sorption process. The gravimetric method, considered a modern method, is being increasingly used in the study of sorption. It is the only method that directly measures the amount of the sorbed substances.

\subsection{The type of measurement}

The measurements included a series of sorption and desorption isotherms of methane on a coal sample at various temperatures in the range of $291 \mathrm{~K}$ to $331 \mathrm{~K}$. The maximum pressure of sorption was 1.7 MPa. Each measurement of the sorption/desorption at a given temperature was preceded by outgassing by turbomolecular pump during $1440 \mathrm{~min}$ at $T_{o}=353 \mathrm{~K}$. Using the same steps of pressure $(0.4 \mathrm{MPa})$ and the same gradient changes in the pressure in the gravimetric device $(333 \mathrm{~Pa} / \mathrm{s})$ allows a comparison of different sorption kinetics.

\subsection{Tested coal}

The study was conducted on bright coal from the coal seam 404/1, coal mine "Pniówek", located in Pawłowice, in the southern part of the Upper Silesian Coal Basin (USCB). Some information about the USCB can be found in the papers by Probierz, Marcisz (2010); Kędzior and Jelonek (2013). The maceral composition of coal is as follows: vitrinite: $73.85 \%$, inertynite: $15.16 \%$, liptynite: $2.20 \%$. Vitrinire reflectance $\mathrm{Rr}=1.08$, volatile matter content $\mathrm{V}_{\mathrm{daf}}=27.3 \%$.

The graphs in Figure 1 show the sorption and desorption isotherms obtained for pressures to $1.7 \mathrm{MPa}$ at temperatures ranging from $291 \mathrm{~K}$ to $331 \mathrm{~K}$. The temperature rise of the coal-methane system causes a decrease of in sorption capacity, which is a known phenomenon (Ji et al. 2012; Bustin, Clarkson 1998; Wierzbicki, Dutka 2010).

The graphs in Figure 2 show the initial $(500 \mathrm{~min})$ changes in methane adsorption on coal samples at different temperatures, at the pressure $p=0.1 \mathrm{MPa}$. The changes in sorption in each case were normalized to a value of 1 . The direct results of the measurements show differences between diffusion kinetics at various temperatures. The order of the curves on the graph demonstrates that increase. The order of the curves on the graph indicates that the temperature rise of the coal-methane system results in the increased kinetics of sorption/ /diffusion. For example, after $250 \mathrm{~min}$ at $331 \mathrm{~K}$, carbon sorption was over 99\%; and at 


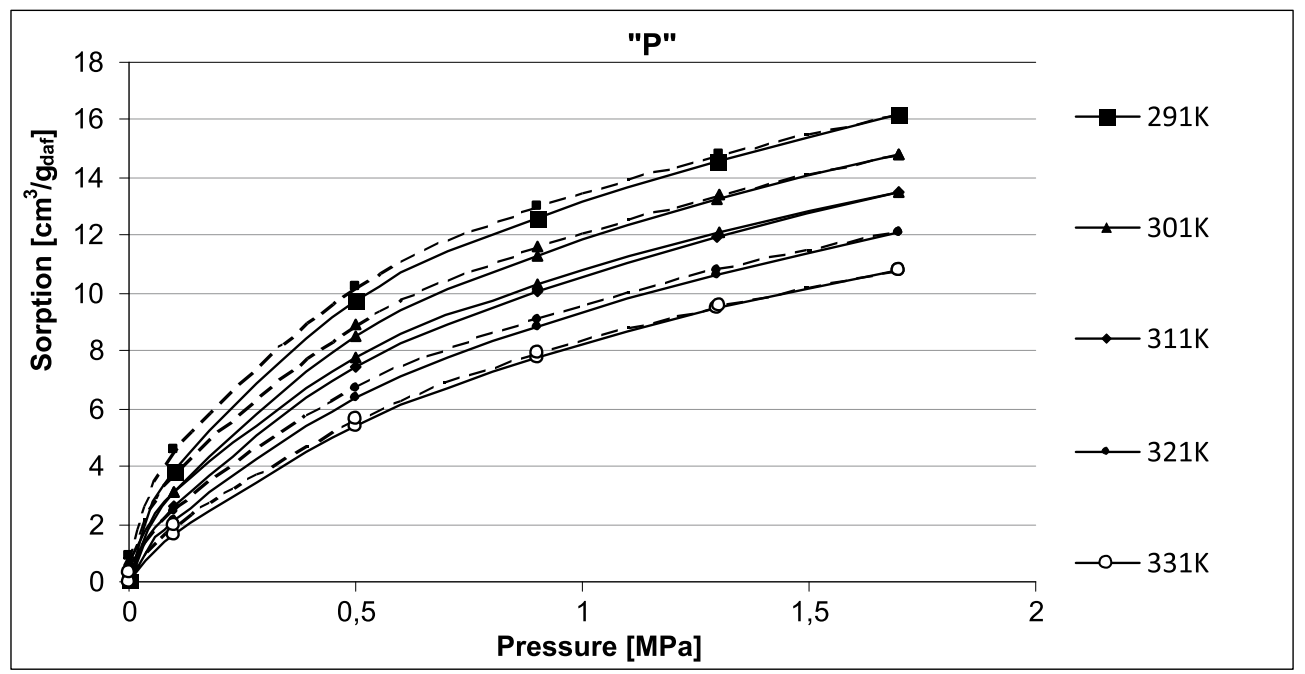

Fig. 1. Methane sorption isotherms for different temperatures

Rys. 1. Izotermy sorpcji metanu w różnych temperaturach

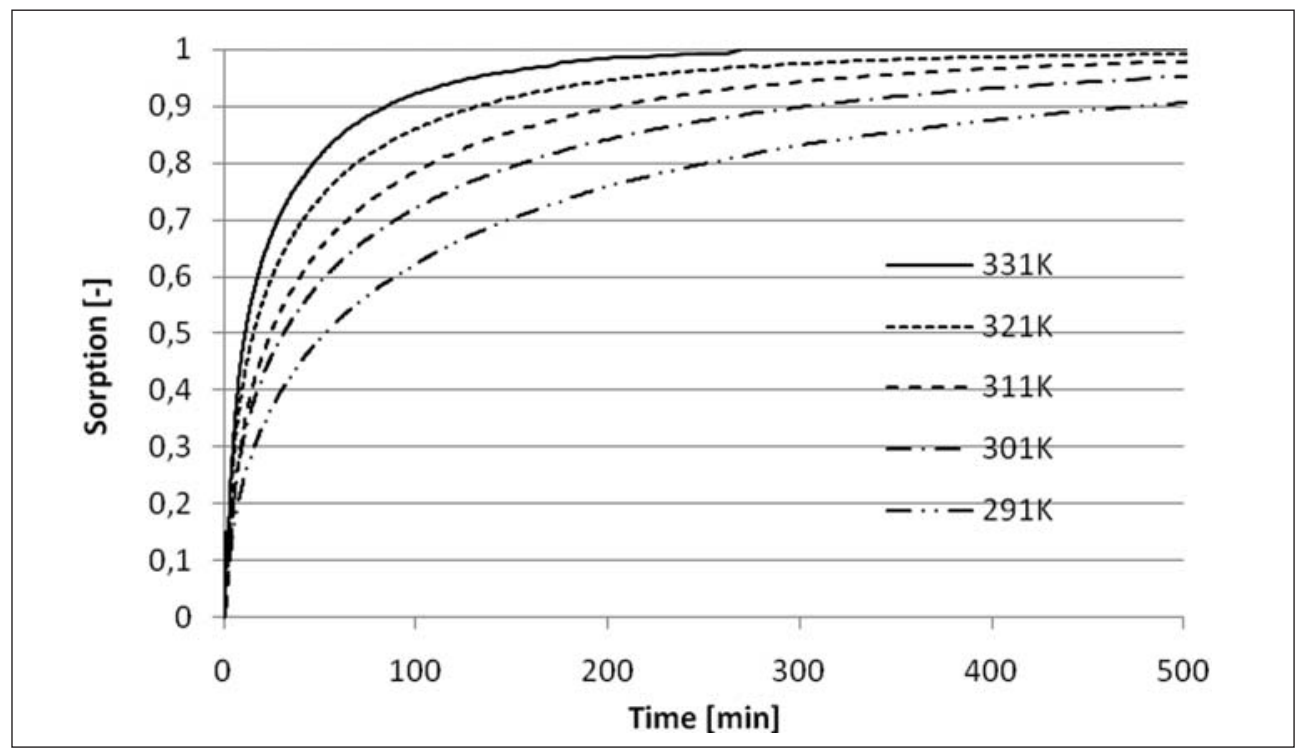

Fig. 2. Sorption kinetics of methane on coal at various temperatures at the pressure of $0.1 \mathrm{MPa}$ Rys. 2. Kinetyki sorpcji metanu na węglu w różnych temperaturach, przy ciśnieniu równowagowym $0,1 \mathrm{MPa}$ 
a temperature of $291 \mathrm{~K}$, the advancement sorption was less than $80 \%$. Based on the kinetics of sorption, the values of diffusion coefficients $D$ from equation (1) were calculated. The variability of diffusion coefficients as a function of the temperature of the coal-methane system is shown in Figure 3. The branches are examined isobars made for the equilibrium pressure from $0.5 \mathrm{MPa}$ to $1.7 \mathrm{MPa}$. The graph shows that the increase in temperature causes an increase in the diffusivity described by the diffusion coefficient $D$ from Crank's equation. In the measured temperature range, the relationship between the temperature and the diffusion coefficient is close to linear. The straight lines fit the measured data points shown in the graphs. The changes in the diffusion coefficients over the range of pressures and temperatures are from $4 \times 10^{-11} \mathrm{~cm}^{2} \mathrm{~s}^{-1} \mathrm{~K}^{-1}$ (for the sorption from 1.3 MPa to $1.7 \mathrm{MPa}$ ) to $6 \times 10^{-11} \mathrm{~cm}^{2} \mathrm{~s}^{-1} \mathrm{~K}^{-1}$ (for the sorption from $0.1 \mathrm{MPa}$ to $0.5 \mathrm{MPa}$ ). The positioning of the lines on the graph shows that the diffusion coefficient also depends on the equilibrium pressure. The pressure effect on the kinetics of the methane sorption process on coal is shown in the graphs of Figure 4. The greatest diffusion coefficient changes, caused by temperature changes, occur at low pressures. The diffusion coefficient values' increase, caused by the temperature increase of $40 \mathrm{~K}$ at a pressure of $0.5 \mathrm{MPa}$, is more than $100 \%$ in relation to the initial value for $T=291 \mathrm{~K}$. For $p=1.7 \mathrm{MPa}$, the change in the value of the diffusion coefficient $D$ was about $1.7 \times 10^{-9} \mathrm{~cm}^{2} / \mathrm{s}$, which is an approximately $80 \%$ increase.

The following graphs from Figure 5 show the timing courses of methane desorption at different temperatures. Sorption/desorption measurements are time consuming. Carrying out all of the measurements on a one coal sample, at five temperatures, (including outgassing) required nearly four months of operation of the gravimetric device.

The graphs in Figure 5 were the basis for determining the diffusion coefficients in the process of desorption of methane from coal. The values of the coefficients were determined numerically, as in the case of sorption. Figure 6 shows two curves. One of them (blue line) shows the sorption kinetics of methane on coal. The second one (the red line) shows the volatility function $\left(1-a_{\mathrm{des}}(t)\right)$, where $a_{\mathrm{des}}(t)$ is the amount of desorption for time $t$. Sorption and desorption measurements were performed under the same conditions. The pressure varied from $0.1 \mathrm{MPa}$ to $0.5 \mathrm{MPa}$ for sorption and from $0.5 \mathrm{MPa}$ to $0.1 \mathrm{MPa}$ for desorption processes. The curves show the kinetics of the sorption and desorption processes that can be directly compared. Under these conditions, the sorption and desorption processes are not fully symmetrical. The sorption curve lies above the desorption curve, which means that the sorption process was faster. The following graphs in Figure 7 show diffusion coefficient changes during sorption and desorption processes as a function of temperature. The graphs refer to the same sorption/desorption pressure changes. The diagrams from Figure 7 show that at pressures up to $1.3 \mathrm{MPa}$, the sorption of methane on coal is slightly faster than the desorption. The largest differences occur at low equilibrium pressures. With increasing pressure, the differences between the diffusion coefficients are decreasing. At a pressure above 1.3 MPa, the processes of the sorption/desorption appear to be symmetrical. The results confirm the thesis that was established, that the value of the diffusion coefficient is dependent on pressure. 


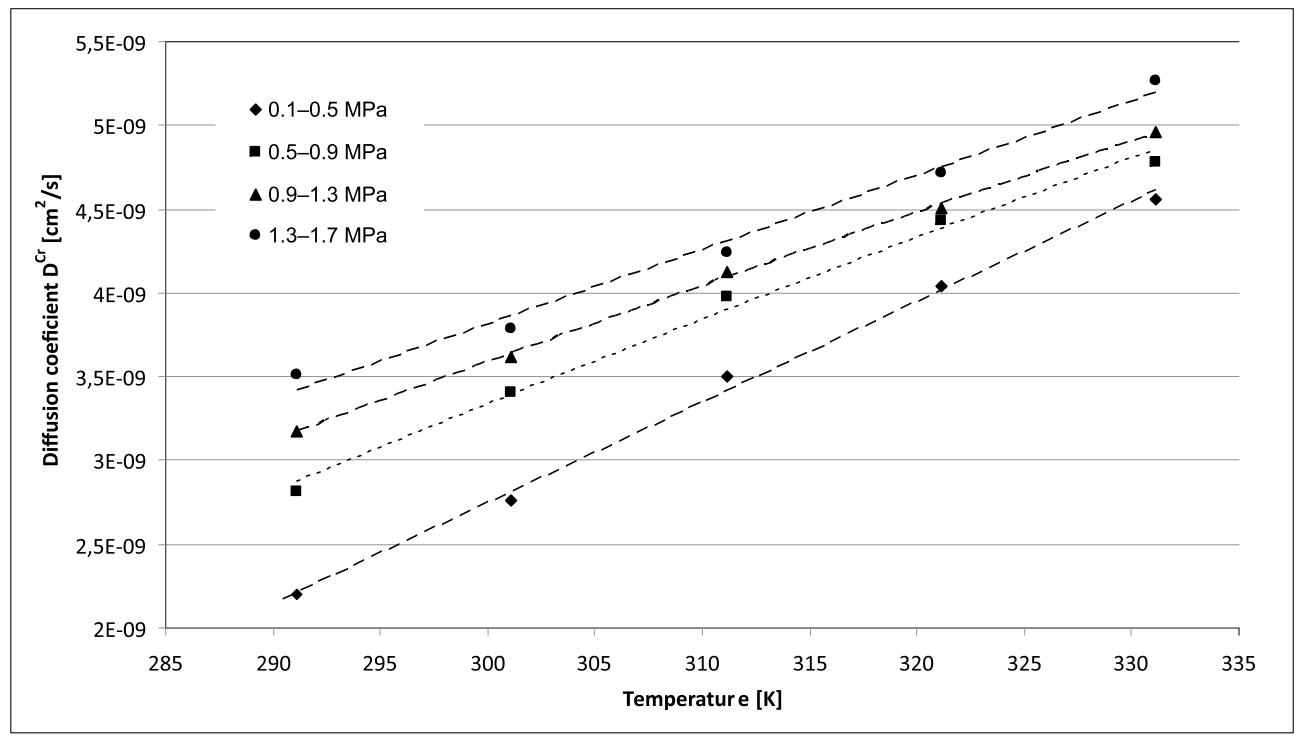

Fig. 3. The dependence of the diffusion coefficient on temperature

Rys. 3. Zależność współczynnika dyfuzji od temperatury

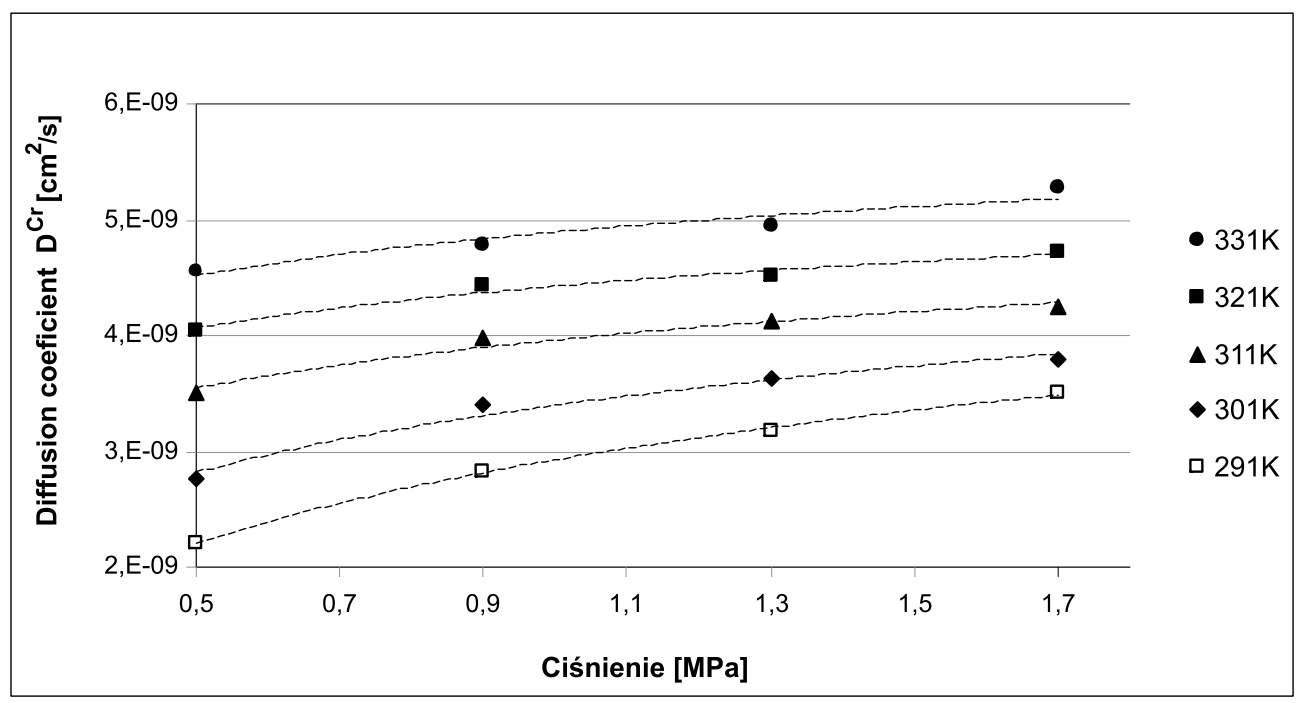

Fig. 4. The dependence of the diffusion coefficient on pressure

Rys. 4. Zależność współczynnika dyfuzji od ciśnienia 


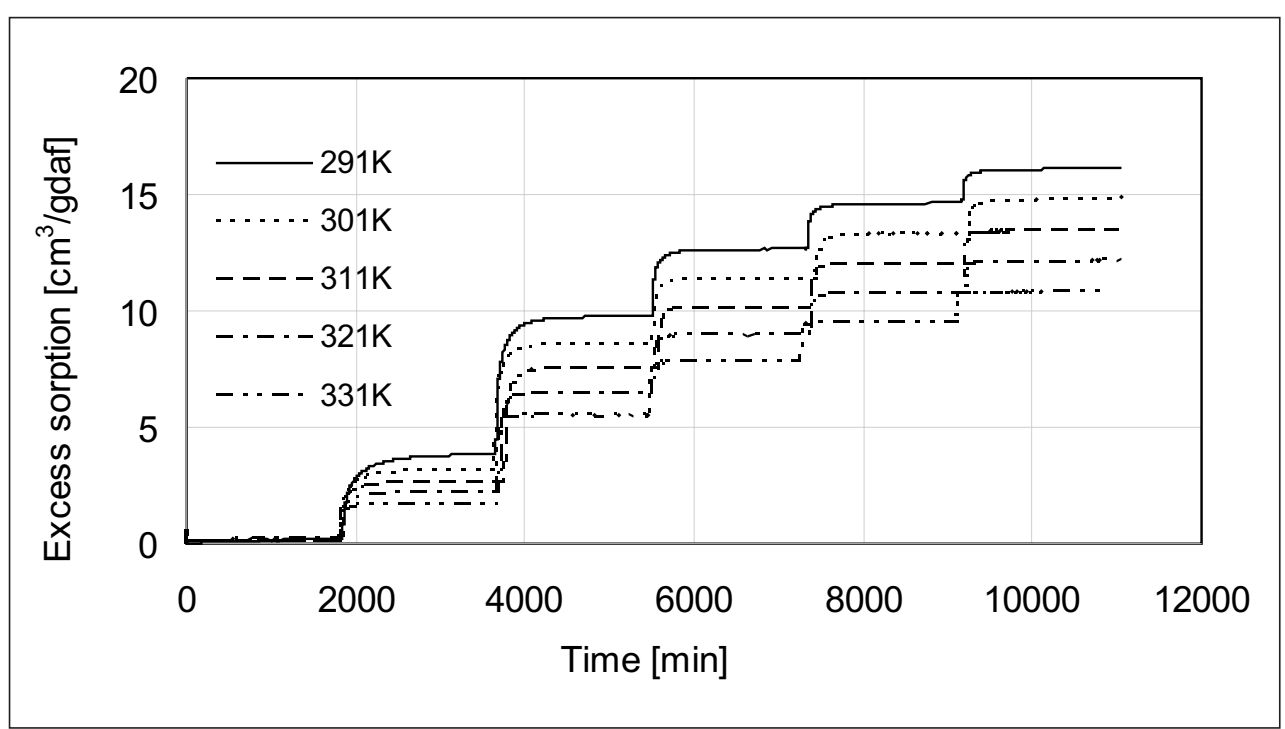

Fig. 5. Desorption kinetics of methane from coal at various temperatures

Rys. 5. Kinetyki desorpcji metanu w różnych temperaturach

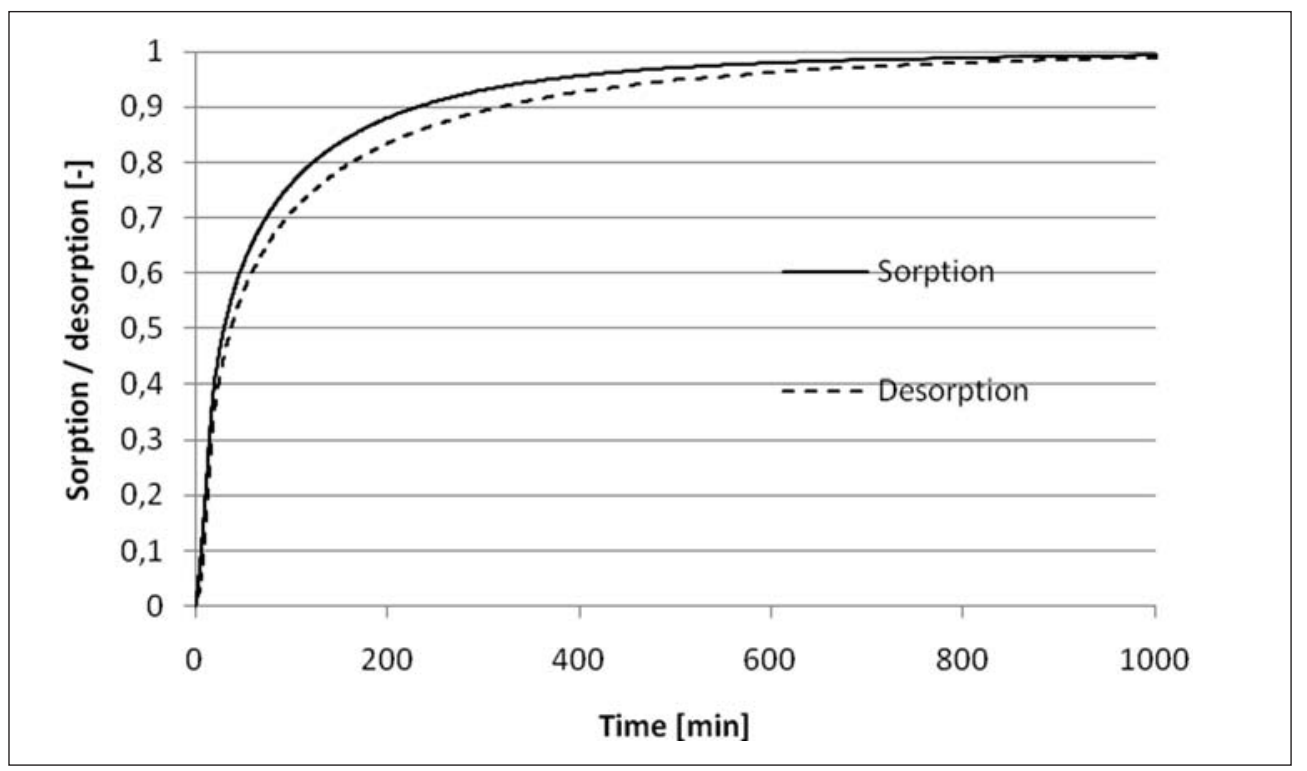

Fig. 6. Sorption (0.1-0.5 MPa) and desorption (0.5-0.1 MPa) methane kinetics on coal at temperature $291 \mathrm{~K}$ Rys. 6. Kinetyki sorpcji (0.1-0.5 MPa) i desorpcji (0.5-0.1 MPa) metanu w temperaturze $291 \mathrm{~K}$ 

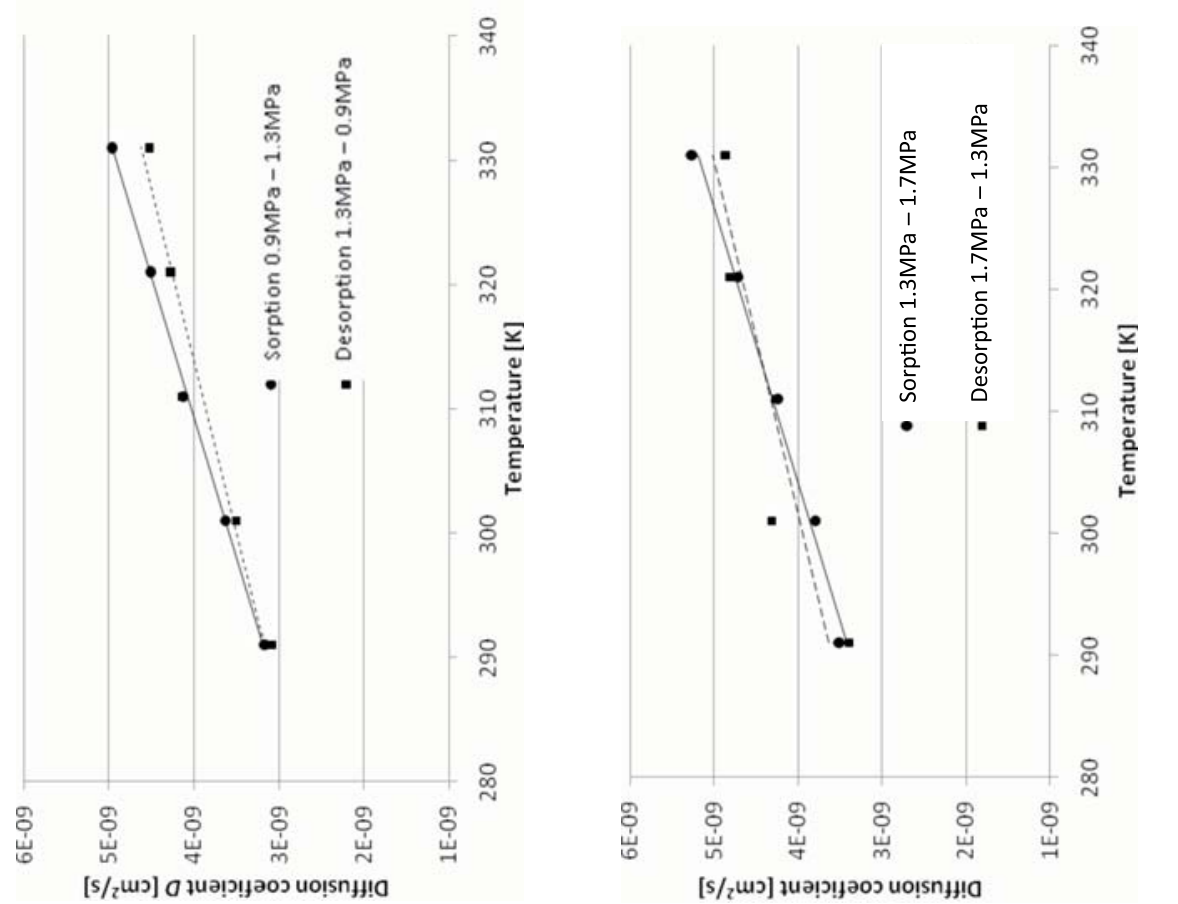

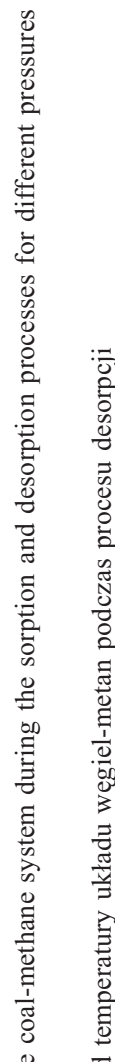
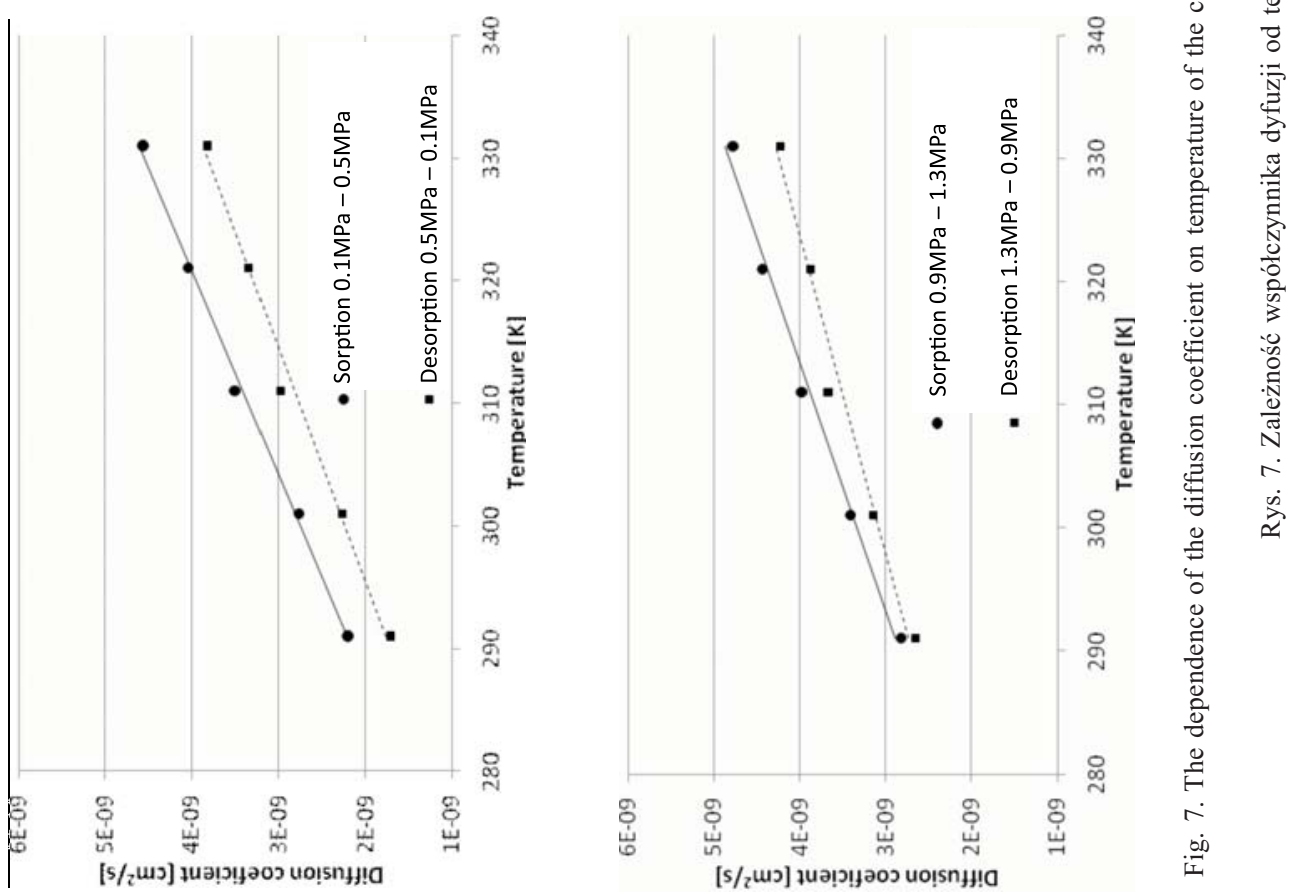


\section{Diffusion coefficient changeability according to the Timofeev conception}

\subsection{Timofeev's considerations about diffusion}

In 1967, the book by D.L. Timofeev titled "Adsorptions Kinetik" was published. The author intentionally defined the $D$ parameter in diffusion equation (1) as the "effective diffusion coefficient". In this paper, the Timofeev coefficient is denoted as $D_{\mathrm{e}}^{\text {Tim }}$, unlike the coefficient from Crank's interpretation $\left(D^{\mathrm{Cr}}\right)$. Thus $D_{\mathrm{e}}^{\mathrm{Tim}} \leftrightarrow D^{\mathrm{Cr}}$. Timofeev proposes to determine the values of the coefficient $D_{\mathrm{e}}{ }^{\text {Tim }}$ based on the knowledge of the sorption half-time and the radius of the grain from the equation:

$$
D_{\mathrm{e}}^{\operatorname{Tim}}=\frac{0.308 R^{2}}{\pi^{2} t_{1 / 2}}
$$

$t_{1 / 2}[\mathrm{~s}] \quad-$ the time after which the sorption reaches $1 / 2 v(\infty)$

This equation results from the solution of the equation for the unipore model at the time when the sorption is $1 / 2 v(\infty)$ :

$$
\frac{v(t)-v(\infty)}{v(0)-v(\infty)}=\frac{6}{\pi^{2}} \sum_{1}^{\infty}\left[\frac{1}{n^{2}} \exp \left(-\frac{n^{2} \pi^{2} D_{e}{ }^{2} t}{r^{2 i m}}\right)\right]=0.5
$$

The values of the coefficients $D^{\mathrm{Cr}}$ obtained from the numerical solution of equation (1) and $D_{e}^{\text {Tim }}$ from the Timofeev equation (2) for the measurements made by the gravimetric method are shown in Figure 8. The very similar results obtained through both methods show that equations 1 and 2 can be used interchangeably.

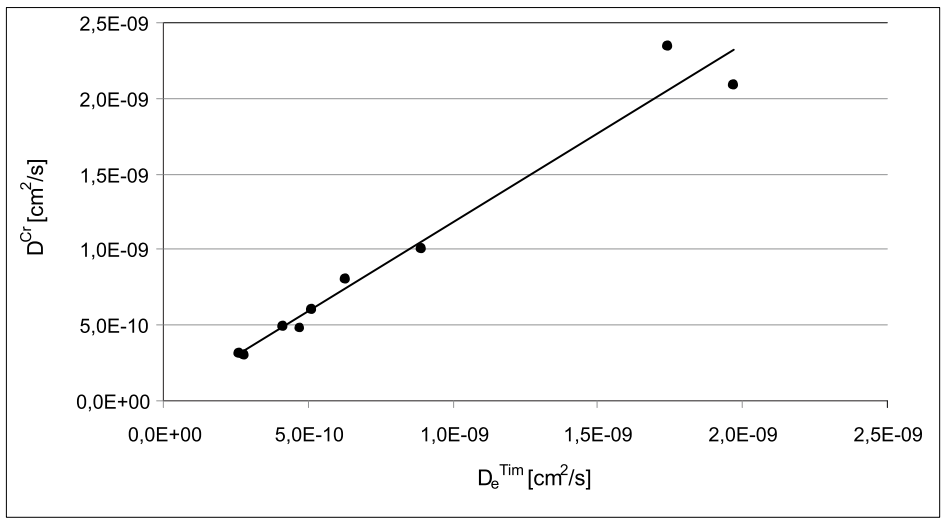

Fig. 8. The values of diffusion coefficients determined from equations (1) and (2)

Rys. 8. Wartości współczynników dyfuzji wyznaczone z rozwiązania równań (1) i (2) 
Timofeev was aware of the role played by the sorption isotherm in the kinetics of diffusion. He defined the diffusion coefficient as follows:

$$
D^{\operatorname{Tim}}=\frac{D_{e}^{\operatorname{Tim}} \varepsilon}{k^{2}(1+\Gamma)}
$$

where:

$$
\begin{aligned}
& D_{e}^{\text {Tim }}-\text { effective diffusion coefficient (by Timofeev) }\left[\mathrm{cm}^{2} / \mathrm{s}\right], \\
& \Gamma-\text { the coefficient of Henry's isotherm, } \\
& D^{\text {Tim }}-\text { diffusion coefficient }\left[\mathrm{cm}^{2} / \mathrm{s}\right] \\
& \varepsilon \quad-\text { the porosity of coal, } \\
& k \quad-\text { labyrinth factor. }
\end{aligned}
$$

Let us assume that the values $\varepsilon$ and $k$ are independent of pressure. At constant temperature, the value of the diffusion coefficient $D^{\text {Tim }}$ should be proportional to the value of the phrase $D_{\mathrm{e}}$ Tim $(1+\Gamma)$. For Langmuir sorption isotherms, the value of $(1+\Gamma)$ will decrease with the increasing pressure. Since the Langmuir isotherm tends to the asymptotic value, for $p \rightarrow \infty, D^{\text {Tim }} \rightarrow D_{e}^{\text {Tim }} k^{2} \varepsilon^{-1}$. If the value of the $D_{e}^{\text {Tim }}(1+\Gamma)$ is constant, independent of $p$, then the diffusion coefficient by Timofeev:

$$
D^{\operatorname{Tim}}=D_{\mathrm{e}}^{\operatorname{Tim}}(1+\Gamma) \mathrm{k}^{2} \varepsilon^{-1}
$$

could be considered as a material constant.

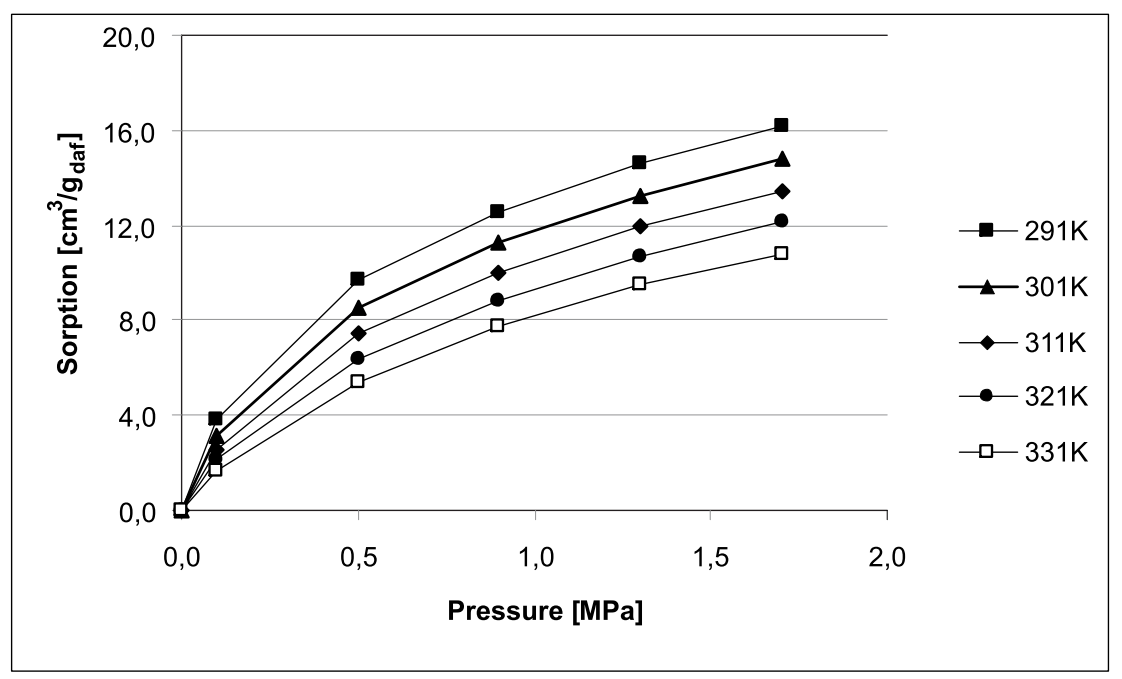

Fig. 9. Sorption isotherms as polylines

Rys. 9. Izotermy sorpcji jako krzywe łamane 


\subsection{Analysis of the results of sorption according to Timofeev's concept}

This study also examined whether or not the diffusion coefficients according to Timofeev's concept may havea constant value, independent of pressure. For this purpose, directional coefficients from polylines of sorption isothermes (Fig. 9) were determined. It was assumed that these coefficients are the coefficients of Henry's isotherm $\Gamma(p, T)$. The results are shown in the graphs in Figure 10. It seems that the values of $D_{e}^{\text {Tim }}(1+\Gamma)$ are linear and depend on temperatures. In the temperature range from $311 \mathrm{~K}$ to $331 \mathrm{~K}$, the straight lines are close to the parallel of the " $x$ " axis (independent of the pressure). The straight lines fitted into the points calculated for temperatures $291 \mathrm{~K}$ and $301 \mathrm{~K}$ have a growing course of pressure. The data does not support an answer to the question of whether the coefficient of the $D^{\text {Tim }}$ equation (4) is a pressure independent constant.

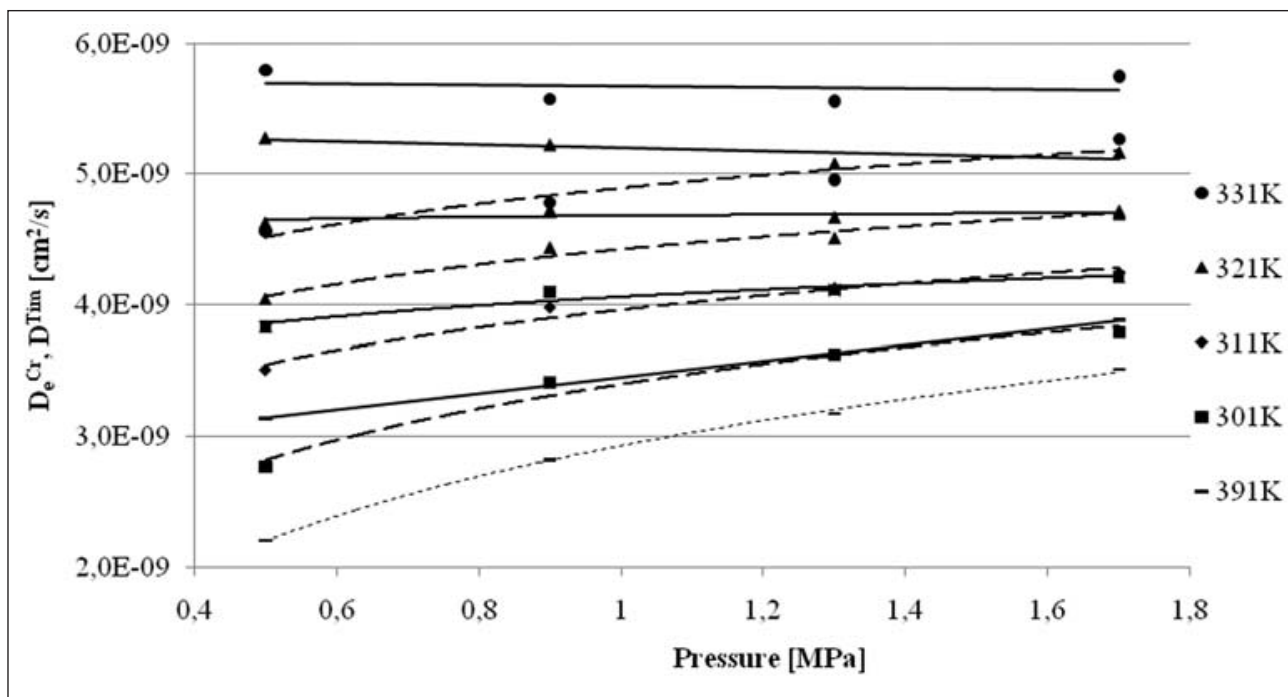

Fig. 10. Crank's $D^{\mathrm{Cr}}$ (the dotted line) and Timofeev's $D^{\mathrm{Tim}}$ (the continuous lines) diffusion coefficients vs. sorption pressure

Rys. 10. Zależności wartości współczynników dyfuzji według Cranka $D^{\mathrm{Cr}}$ (linie przerywane) oraz Timofieewa $D^{\text {Tim }}$ (linie ciagłe) od ciśnienia sorpcji

\section{Conclusions}

The presented research allowed for the determination of the kinetic properties of the coal-methane system. The unipore diffusion model was used for the description of these properties. Conclusions from this study are as follows: 
- The methane diffusivity of the tested coal from the USCB (Poland) increases with increasing temperature and pressure.

- The relationship between the diffusion coefficient $D^{\mathrm{Cr}}$ of solution (1) and temperature can be described by a linear function.

- The effect of temperature on the diffusion coefficient $D^{\mathrm{Cr}}$ decreases with the increase in the sorption pressure (from about $6 \times 10^{-11} \mathrm{~cm}^{2} \mathrm{~s}^{-1} \mathrm{~K}^{-1}$ at the pressure $p=0.5 \mathrm{MPa}$ to $4 \times 10^{-11} \mathrm{~cm}^{2} \mathrm{~s}^{-1} \mathrm{~K}^{-1}$ at the pressure $p=1.7 \mathrm{MPa}$ ).

- The diffusion coefficients $D^{\text {Tim }}$ according to Tomofeev's concept (4) have a lower variability than diffusion coefficients from equation (1). For temperatures above $311 \mathrm{~K}$, the coefficient $D^{\text {Tim }}$ appears to be independent of the pressure. The study does not allow for an unambiguous confirmation (or negation) of the supposition that the diffusion coefficient $D^{\text {Tim }}$ is a material constant.

- The tested coal has positive hysteresis in the sorption and desorption processes. At pressures below $1 \mathrm{MPa}$, the sorption of methane in coal is slightly faster than the desorption. The difference in the values of diffusion coefficients at a pressure of $0.5 \mathrm{MPa}$ is about $20 \%$. At higher pressures (above 1.3 MPa) the sorption/desorption kinetics are very similar.

- The diffusion coefficient $D^{\mathrm{Cr}}$ from solution (1) is dependent on pressure, which means that $D^{\mathrm{Cr}}$ is not a material constant. To compare the results of measurements, they must be conducted within the same pressure ranges.

This work was partially supported by The National Centre for Research and Development Grant No. Nr LIDER/31/103/L-3/11/NCBR/2012

\section{REFERENCES}

Bhowmik S., Dutta P., 2013 - Adsorption rate characteristics of methane and $\mathrm{CO}_{2}$ in coal samples from Raniganj and Jharia coalfields of India, Volume 113, International Journal of Coal GeologyComplete, 50-59.

Busch A., Gensterblum Y., $2011-\mathrm{CBM}$ and $\mathrm{CO}_{2}-\mathrm{ECBM}$ related sorption processes in coal: A review, International Journal of Coal Geology 87, 49-71.

Busch et al. 2004 - Busch A., Gensterblum Y., Krooss B.M., Littke R., 2004 - Methane and carbon dioxide adsorption-diffusion experiments on coal: upscaling and modeling. International Journal of Coal Geology 60, 151-168.

Bust in R.M., Clarks on C.R., 1998 - Geological controls on coalbed methane reservoir capacity and gas content, International Journal of Coal Geology Volume 38, Issue 1-2, 3-26.

Charriere et al. 2010 - C h arriere D., P o kry s zk a Z., B e hra P., 2010 - Effect of pressure and temperature on diffusion of $\mathrm{CO}_{2}$ and $\mathrm{CH}_{4}$ into coal from the Lorraine basin (France). International Journal of Coal Geology $81,373-380$

C l a rk s o n C.R., B u s t in R.M., 1999 - The effect of pore structure and gas pressure upon the transport properties of coal: a laboratory and modeling study, 2. Adsorption rate modeling, Fuel 78, 1345-1362.

Crank J., 1975 - The Mathematics of diffusion, 2nd ed. Oxford Univ. Press, London. 414.

Cui et al. $2004-\mathrm{Cu}$ i X., Bustin M.C., Dipple G., $2004-$ Selective transport of $\mathrm{CO}_{2}, \mathrm{CH}_{4}$ and $\mathrm{N}_{2}$ in coals: insights from modeling of experimental gas adsorption data. Fuel 83, 293-303. 
Czerw K., Ceglarska-S te fańska G., 2008 - Dynamika deponowania gazów kopalnianych w strukturze porowatej węgla kamiennego. Mineral Resources Management (Gospodarka Surowcami Mineralnymi) t. 24, z. 3, pp. 57-67.

Han et al. 2013 - Han F., Busch A., Krooss B.M., Liu Z., Yang J., $2013-\mathrm{CH}_{4}$ and $\mathrm{CO}_{2}$ sorption isotherms and kinetics for different size fractions of two coals. Fuel 108, 137-142.

Ji et al. 2012 - Ji L., Zhang T., Milliken K.L., Qu J., Zhang X., 2012 - Experimental investigation of main controls to methane adsorption in clay-rich rocks. Applied Geochemistry 27, 2533-2545.

K a w ę c k a J., 1988 - Sorpcja gazów i par a właściwości polskich węgli kamiennych jako układów dyspersyjnych. Zesz. Nauk. AGH, Chemia, z. 8 (in polish).

Kędzior S., Jelonek I., 2013 - Reservoir parameters and maceral composition of coal in different Carboniferous lithostratigraphical series of the Upper Silesian Coal Basin, Poland, International Journal of Coal Geology 111, 98-105.

King G.R., Ertekin T.M., 1989 - A survey of mathematical models related to methane production from coal seams, Part II: Nonequilibrium sorption models. Coalbed Methane Symp. The Univ. of Alabama, Tuscaloosa, $139-155$.

Kovaleva I.B., Solov'eva E.A., 2006 - Movement and sorption of liquids and gases in porous media. Dependence of methane sorption kinetics on coal structure, Journal of Mining Science, Vol. 32, No. 2, $122-128$.

Lamberson M.N., Bustin R.M., 1993 - Coalbed methane characteristics of the Gates Formation coals, northeastern British Columbia: effect of maceral composition. American Association of Petroleum Geologists Bulletin 77, 2062-2076.

L a x m in a r a y n a C., C r o s d a le P.J., 2002 - Controls on methane sorption capacity of Indian coals. American Association of Petroleum Geologists Bulletin 86, 201-212.

Młynarczuk M., Wi erzbicki M., 2009 - Stereological and profilometry methods in detection of structural deformations in coal samples collected from the rock and outburst zone in the "Zofiówka" colliery. Archives of Mining Sciences 54, issue 2, 189-201

N an d i S.P., Walker Jr., P.L., 1975 - Activated diffusion of methane from coals at elevated pressures. Fuel 54, $81-86$.

Nowak G.J., 2004 - Facies studies of bituminous coals in Poland. International. Journal of Coal Geology 58, 61-66.

Patyńska R., 2013 - Methane emissions from ventilation and degasification systems of hard coal mines in Poland in the years 2001-2010. Mineral Resources Management (Gospodarka Surowcami Mineralnymi) t. 29 , pp. $17-33$

Pillalamarry et al. 2011 - P ill a l a marry M., Harpa la ni S., Li u S., 2011 - Gas diffusion behavior of coal and its impact on production from coalbed methane reservoirs. International Journal of Coal Geology 86, $342-348$.

Probierz K., Marcisz M., 2010 - Changes of coking properties with depth of deposition in coal seams of Zofiówka monocline (SW part of Upper Silesian Coal Basin, Poland). Mineral Resources Management (Gospodarka Surowcami Mineralnymi) t. 26, z. 4, pp. 71-87.

Saghafi et al. 2007 - Sagh afi A., Faiz M., Roberts D., $2007-\mathrm{CO}_{2}$ storage and gas diffusivity properties of coals from Sydney Basin. Australia International Journal of Coal Geology Volume 70, Issue 1-3, $240-254$.

S k o c zylas N., 2012 - Laboratory study of the phenomenon of methane and coal outburst. International Journal of Rock Mechanics \& Mining Sciences, 55,102-107.

Sk oczylas N., 2012a - Coal Seam Methane Pressure as a Parameter Determining the Level of the Outburst Risk - Laboratory and in Situ Research. Archives of Mining Sciences. Volume 57, Issue 4, 861-869.

Skotniczny P., 2009 - Dynamic Phenomena in the Air Flow in a Mine Drift Caused by Rock and Gas Outbursts, Archives of Mining Sciences, Vol. 54, Issue 4, pp. 827-840.

Skotniczny P., 2013 - Three Dimentional Numerical Simulation of the Mass Exhange Between Longwall Headings and Goafs, in the Presence of Methane Drinage in a U-type Ventilated Longwall. Archives of Mining Sciences, Vol. 58, Issue 4, pp. 705-718. 
Timofejew D.P., 1967 - Adsorption kinetic. Leipzig, 335 pp.

Wierzbicki M., Dutka B., 2010 - The influence of temperature changes of the structurally deformed coal-methane system on the total methane content. Arch. Min. Sci., Vol. 55, No. 3, 547-560

\section{ZMIANY KINETYKI PROCESÓW SORPCJI/DYFUZJI W UKLADZIE WĘGIEL-METAN WYWOLANE ZMIANAMI TEMPERATURY I CIŚNIENIA}

\section{Słowa kluczowe}

Sorpcja metanu, kinetyka sorpcji, współczynnik dyfuzji, model uniporowy

\section{Streszczenie}

W artykule przedstawiono wyniki pomiarów kinetyki adsorpcji metanu na węglu wykonane metodą grawimetryczną. Rejestracja czasowych zmian sorpcji metanu na węglu oraz wykorzystanie uniporowego modelu dyfuzji pozwoliło na wyznaczenie współczynników dyfuzji metanu na węglu w temperaturach od $291 \mathrm{~K}$ do $331 \mathrm{~K}$ i przy ciśnieniach do 1,7 MPa. Wyniki pokazują, że wartość współczynnika dyfuzji rośnie ze wzrostem temperatury. Zależność pomiędzy temperaturą a współczynnikiem dyfuzji wydaje się być liniowa. Badania desorpcji wykonane w warunkach takich jak pomiar sorpcji pokazały, że przy niższych ciśnieniach sorpcja jest procesem prze- biegającym szybciej. Różnice w kinetykach zanikają przy ciśnieniu około 1,3 MPa. Wartość współczynnika dyfuzji zależna jest również od ciśnienia równowagowego, co wskazuje, że współczynnik ten nie jest stałą materiałową układu węgiel-gaz. W pracy przypomniano również rozważania Timofeewa na temat współczynnika dyfuzji. Autor ten wiąże współczynnik dyfuzji z liniową izotermą Henry’ego. Wyniki pokazują, że współczynnik dyfuzji według koncepcji Timofeewa charakteryzuje się mniejszą zmiennością wywołaną zmianami ciśnienia w porównaniu z koncepcją Crank’a. W temperaturach powyżej $311 \mathrm{~K}$ współczynnik dyfuzji według Timofeewa wydaje się być niezależny od ciśnienia.

CHANGES IN THE SORPTION/DIFFUSION KINETICS OF A COAL-METHANE SYSTEM CAUSED BY DIFFERENT TEMPERATURES AND PRESSURES

$$
\text { Key words }
$$

Methane sorption, sorption kinetics, diffusion coefficient, unipore model

$$
\text { Abstract }
$$

This paper presents the results of studies into the kinetic adsorption properties of methane on coal (effective diffusion coefficient) using the gravimetric method. The measurements of the time waveforms of methane sorption on coal and the use of the unipore model of diffusion allowed to determine the diffusion coefficients at different temperatures in the range of $291 \mathrm{~K}$ to $331 \mathrm{~K}$ and pressures up to $1.7 \mathrm{MPa}$. This study have shown that the diffusion coefficient increases with increasing temperature. The relationship between the diffusion coefficient and the temperature of the coal-methane system appears to be linear. The value of the diffusion coefficient of Crank's solution is also affected by methane pressure, which shows that the diffusion coefficient is not a material constant. This analysis also references Timofeev's discussion on the diffusion coefficient, and analyzes the relationship between the coefficient of diffusion and the Henry's isotherm coefficient. Examination has shown that the Timofeev's diffusion coefficients is characterized by less variability when compared to the diffusion coefficients according to Crank's solution. At temperatures above $311 \mathrm{~K}$, the diffusion coefficients by Timofeev seem to be independent of the pressure. 